\title{
DECISION TO WITHDRAW PUBLISHED TEXT Critics and Aspects of the European Citizenship According to the CJEU: From Rottmann to Tjebbes and Others
}

The commission of the Megatrend Review, formed to investigate issue, based on comparison of two scientific papers:

A) Da Rottmann a Tjebbes e.a.: riflessioni sulla giurisprudenza della Corte di giustizia in materia di cittadinanza europea, ISSN 2284-3531,

published at the Ordine internazionale e diritti umani, (2019), pp. 997-1014., http://www.rivistaoidu.net/sites/default/files/8_Orzan.pdf; and

B) Critics and Aspects of the European Citizenship According to the CJEU: From Rottmann to Tjebbes and Others, doi:10.5937/MegRev2001001L, published at the Megatrend Review Vol. 17, № 1, 2020: 1-26, http://megatrend.edu.rs/wp-content/uploads/2020/04/Megatrend_revija_ Vol_17_No_1_2020_WEB.pdf

concluded on October $13^{\text {th }} 2020$ that some parts of the original paper (A) in Italian language have been used without proper quotations in the paper (B) in the English language.

Following this conclusion, the Commission proposed to the Editorial Board to officially withdraw paper (B) electronically published in Megatrend Review №. 1 in 2020. Notification of the withdrawal will be issued in Megatrend Review №. 3 in December 2020.

The Editorial Board has accepted the proposal related to the above-mentioned text. 